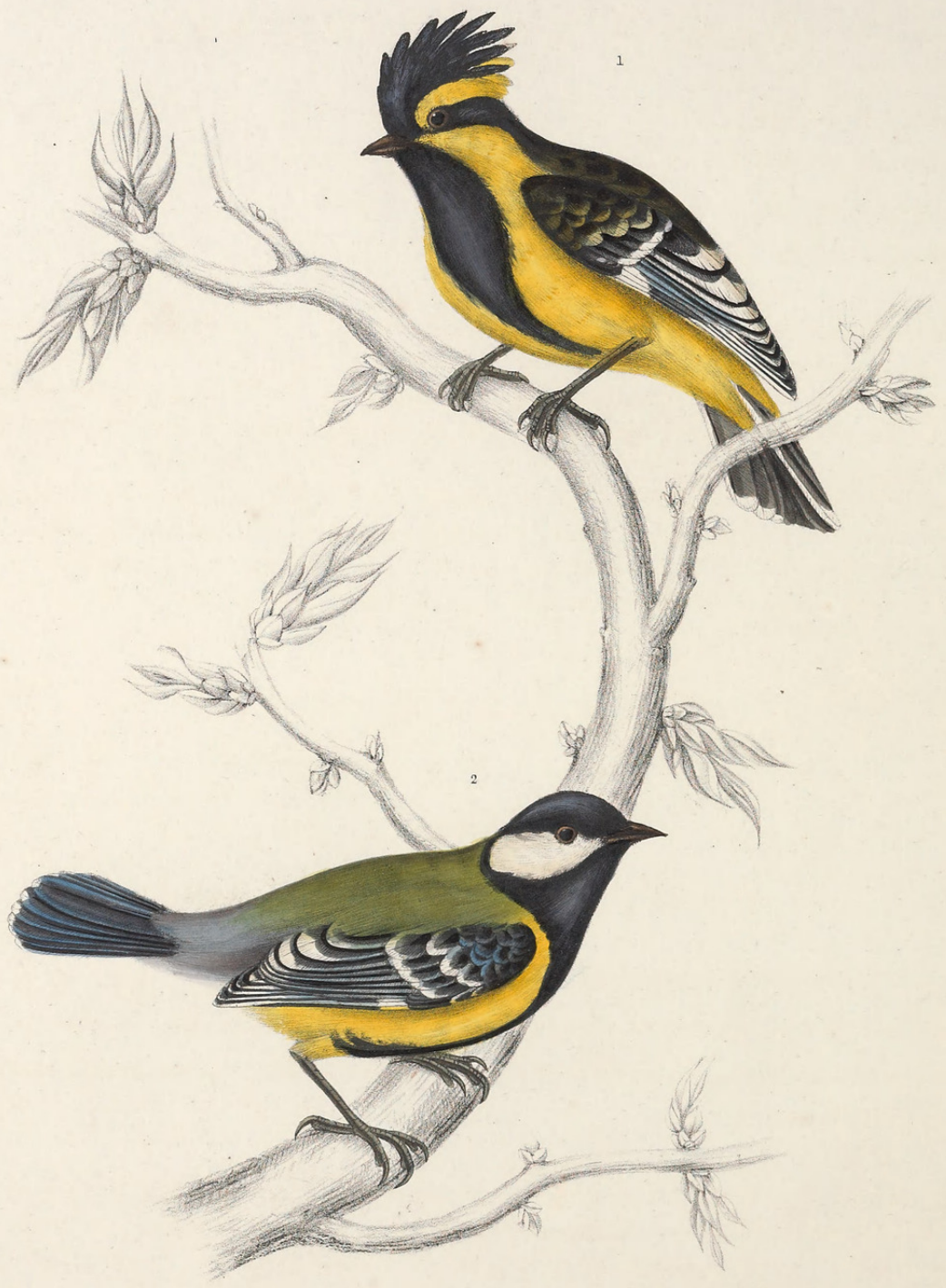

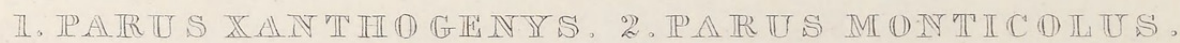


TAB. XXIX. Fig. 1.

\section{PARUS XANTHOGENYS.}

Par. capite cristato, gulâ, pectore, abdomine medio, strigâ utrinque colli, scapularium maculis, alis, caudâque atris, his albo notatis; dorso scapularibusque virescenti-griseis; genis, strig $\hat{a}$ superciliari, maculâ nuchali, abdominisque lateribus favis.

Staturâ paulò minor Par. majori.

ONE of the largest species of Parus which has yet been discovered, is the very pretty species given in this Plate, fig. 1., equalling in size our well-known Parus major, to which Parus Xanthogenys bears a close resemblance, and from which it differs chiefly by its crested head. The brilliancy of its colouring is not surpassed by that of any of its congeners, and its mode of life assimilates strictly to the habits of the Pari in general.

The head is furnished with a full crest of black feathers; the occiput, superciliary stripe and cheeks, are yellow; the ear-coverts black; the back olive; the wings and tail are black, the former being spotted with white, the latter tipped with white; a broad black line passes down the throat and extends along the middle of the abdomen; the sides of the chest, and flanks are pale yellow ; the beak and legs black.

TAB. XXIX. Fig. 2.

\section{PARUS MONTICOLUS.}

Par. capite, collo, pectore, abdomine medio, alis rectricibusque atris; genarum maculâ latâa nuchalique parvâ, tegminum remigum secundariarum rectricumque apicibus, et remigum primariarum rectricumque, lateralium pogoniis externis albis; abdominis lateribus favis.

Statura præcedentis.

THE higher regions of the Himalayan Mountains are reported to us as being the localities through which this species is chiefly distributed; whence its specific name has been derived, to distinguish it from its congeners of the lower lands. It may at once be observed to be closely allied to the Parus major of Europe, but the accurate naturalist will easily detect characters in the bird which lay ample claim to its being recognised as a new and distinct species.

The top of the head, the occiput, the base of the neck, the throat, breast and a broad abdominal line are jet black; the cheeks and a small occipital patch white; the back is olive; the wings black; the edges of the coverts white so as to form a bar across the shoulders; the quills are tipped with white also and edged with blueish; the tail is black with a blueish tinge, the edges of the two outer feathers and the tips of all being white; the flanks are yellow; the beak and tarsi black.

Both these species are figured of the natural size. 


\section{$2 \mathrm{BHL}$ Biodiversity Heritage Library}

Gould, John. 1831. "Parus monticolus [Tab. XXIX]." A century of birds from the Himalaya Mountains -. https://doi.org/10.5962/p.323577.

View This Item Online: https://www.biodiversitylibrary.org/item/132967

DOI: https://doi.org/10.5962/p.323577

Permalink: https://www.biodiversitylibrary.org/partpdf/323577

\section{Holding Institution}

Smithsonian Libraries

\section{Sponsored by}

Biodiversity Heritage Library

\section{Copyright \& Reuse}

Copyright Status: Public domain. The BHL considers that this work is no longer under copyright protection.

This document was created from content at the Biodiversity Heritage Library, the world's largest open access digital library for biodiversity literature and archives. Visit BHL at https://www.biodiversitylibrary.org. 